\title{
Juvenile Boot Camps in the Shadow of Tragedies Magdolna CSUKAI, ${ }^{1}$ Péter RUZSONYI ${ }^{2}$
}

\begin{abstract}
Many pros and cons arguments can be read about boot camps in terms of efficiency and application. My article reviews tragedies and deaths occurred in juvenile boot camps processing their background and causes. It is not my purpose to present boot camps in a negative light but to reveal circumstances of tragedies and on the basis of this to prevent their re-occurrence.
\end{abstract}

Keywords: boot camps, military drill, tragedies

\section{Boot Camps}

\section{Coming to Being}

The idea of boot camps appeared as an alternative to the conventional prison and probation time as it was often experienced-for perpetrators committing a non-violent criminal offence for the first time-that people considered penalty in prison to be too harsh while probation time too lenient. Therefore, in view of such cases, it was deemed necessary to impose new intermediary sanctions such as house custody, electronic surveillance, intensive probation service or boot camp. The latter was one of the most popular forms getting major resonance [1] whose essence is a short "shock prisoning” with a military atmosphere. The roots of its popularity lie in the linked expectations according to which it can reduce recidivation, operational costs and prison population.

Already in 1938, the plan for such boot camp-type of penalty form had been forged for youngsters in England but it was no sooner implemented than in 1948. The then established boot camps were running until the 1970s but did not meet the expectations. [2] The first American new-generation boot camp started operation in Georgia, in 1983, in an adult prison with 50 beds. This soon spread state-wide and such facilities were made not only for adults but youngsters [3] as well, at the time. The first programme developed for youngsters in particular was launched in 1985 in Parish, Orleans, Louisiana. According to statistics, over 75 juvenile boot camp programmes were launched in 33 states [1] in 1997; nowadays this form of penalty can be found all over the world except for Europe. Due to its diversity and variety, several names have been granted for boot camps. ${ }^{3}[2]$

1 Ph.D. student, National University of Public Service, Doctoral School of Military Sciences; e-mail: csukaim@gmail.com

2 Ph.D., Correctional Brigadier-General, University Professor, Pro-Dean, Head of Department of Corrections, Faculty of Law Enforcement, National University of Public Service; e-mail: ruzsonyi.peter@uni-nke.hu

3 For instance, such names are Special Alternative Incarceration, Basic Training Program, Intensive Motivational Program of Alternative Correctional Treatment, Regimented Inmate Discipline, Challenge Incarceration, Shock Incarceration and Detention Centre Programme. 


\section{General Characteristics}

Boot camps established for youngsters may differ in the procedure that applies to the youngsters selected for inclusion in the programme. [4] In general, this does not happen on a voluntary basis but it is the court, prison facility probation service that submits the juvenile perpetrator to a boot camp. However, there are some exceptional cases when a boot camp can host voluntary participants as well; but should in our case if the training be unsuccessful, the person must go to a conventional prison to complete the penalty period. [5]

Youngsters are usually sent to boot camps for a short period of 1 to 6 months, on average 3 months. Thus, the time spent in the camp is brief but all the more intensive as those who have been included must be involved in activities actively for 16 hours daily. [8] This is one of the reasons why the inclusion in such camps is linked to several prerequisites as not everyone is apt to complete such an intensive programme. Although prerequisites vary from programme to programme and from state to state, those who committed no violent criminal offence for the first time may participate in the boot camp programme. By age, generally a wider age range of 10 to 25 years can be considered, [1] but each programme may contain a tighter age range as large difference in the participants' age provides an opportunity for the elders to commit physical abuse to the detriment of the youngers within the camp, [7] consequently this is not recommended. Furthermore, there are camps where age conditions are stricter and participation under 16 is not even allowed because the military drill employed there is overly burdensome for the younger ones. [2] These basic conditions related to the type of criminal offence and age may be complemented with the parent's declaration of consent as well as the necessity of health, physical and psychic fitness.

Based on the critics raised and experience gathered over the years, a continuous development of camps can be detected, during which a transition from the one-to-one copy of military penal camp that broke up both the body and the mind to educational, training programmes was attained. [2] Therefore, nowadays youngsters can participate at various activities after inclusion in a specific boot camp. Currently, most of the juvenile boot camps have three main components: military training in stringent discipline, rehabilitation activities as well as educational and vocational training programmes. [8] These three parts can be interpreted both as a function and a development direction in comparison to the original standard military camps. [6] However, from the point of view of to what degree these areas appear during the programme, large differences can be noticed. Certain camps still place emphasis on discipline and strict physical education, whereas others concentrate on occupational therapy, education and development of capacity for thinking despite the military atmosphere. [3]

\section{Military Drill}

\section{Pros and Cons Arguments}

Military drill is the core characteristic of boot camps, however, there are divergent opinions as to its strong application in juvenile camps. Perhaps this component has been and still is 
exposed to most critics. Also, the interest shown by the media concentrates almost completely on the strict military nature as it has plenty more sensational value than rehabilitation and educational programmes. [6]

In most of the camps, prison officers and detainees wear a military-style uniform and use military terms. The method employed conscientiously by those called drill sergeants is verbal confrontation, which is mainly used to crush the self-esteem of the newly arrived when inclusion takes place [2]: "You are nothing and nobody, fools, maggots, dummies, mother...s, and you have just walked into the worst nightmare you ever dreamed. I don't like you. I have no use for you, and I don't give a f... who you are on the street. This is my acre, hell's half acre, and it matters not one damn to me whether you make it here or get tossed out into the general prison population, where, I promise you, you won't last three minutes before you're somebody's wife. Do you know what that means, tough guys?" [9: 30]—-this is how an opening speech goes in a boot camp. [9] Besides, the military model comprises tough training, military drills, prompt physical punishment applied when behaving inappropriately, a celebration to be held during inclusion and departure and stringent daily schedule, too. [4]

Those in favour of strict military drills claim that soldiers' personality transforms after being drafted, therefore it is the drilling and discipline that are expected to alter the behaviour of youngsters. It is thought that this way a law-breaking youngster may become a person abiding authority, [1] as training transmits valuable elements from a pedagogical point of view such as emphasis on grooming, setting honour, integrity, and professional liability to the fore as well as respecting traditions. [2] Thus, the camp in accordance with this line of thought shocks participants by the tough physical expectations to make them more inclusive towards the change in personality and deter them from further criminal offences. [9]

Against these critics voice the arguments that current psychological research projects focussing on teenagers imply that they do not react to short-term physical load that comprises threats and humiliation. There are those who worry about participants becoming better perpetrators via their better stamina, becoming more disciplined and smarter than their counterparts being in prison. [9] Moreover, this military model provides room for physical and psychic abuse as it can make many forms of penalty legal that other prison regime would refuse due to its cruelty and inhumanity. [2: 7] All these may lead to excesses on the part of the training staff, which, unfortunately, had been presented in several instances during the existence of boot camps.

Moreover, the effectiveness test of boot camps does not support the necessity for strong military drill. In relation to this, Muscar [9] obtained the result that in boot camps which showed any signs towards reduced deterioration, each had an aftercare with intensive supervision. This indicates that weaker recidivation rate occurs thanks to aftercare and not military-based residential period. It is no coincidence that it is a baseline requirement for professionally serious boot camps to have the aftercare arranged as a part of the work of the institution. [6] The same is backed by Wilson, MacKenzie and Michell's comprehensive research, [3] as well. Their findings indicate that the military approach of boot camps is an inefficient method to reduce the recidivation after the camp. 


\section{Selection and Preparation of Personnel}

A well-selected and prepared personnel have a vast role to play in the success of boot camps. It is observed in boot camps mainly created for youngsters that the novel missionary consciousness, the dominance of rehabilitation tasks, dealing with youngsters with a previously clean record renew the personnel's morale. However, unfortunately this is only a preliminary state, serious issues may arise as programmes advance. Since a boot camp exerts an enhanced stress to not only youngsters incorporated but also the training personnel, the negative consequence of a burn-out and high turnover can be more rapidly reached here than in normal prisons. Parallel to the growth in the number of such cases, the possibility of harassment and physical abuse within a camp arising from fault or negligence of the personnel increases. [10] To avoid this, the proper selection of personnel, their preparation for work and their further training at regular intervals are key issues.

Thus, the first step is the selection procedure. In this, at least the following factors need to be addressed by all means, which can be grounds for exclusion: physical abuse or negligence of those put to care or supervision of the person; drug or alcohol abuse; serious personal issues currently existing; reports on previous misconducts. In addition, a requirement for training officers can be the experience gathered in earlier military service and many physical conditions - height, weight, condition - as they should be suitable for carrying out the issued tasks as well and serving as a role model for the youngsters. [11]

The second step is the preparation of the selected persons. A boot camp is a special correctional medium, thus it is important that the personnel understand the concept, purpose and structure of the programme. During the preparation, the future personnel is helped to better understand the participating youngsters and themselves, too. Unfortunately, this preparatory training is neglected in some minor boot camps, however, there are camps where especially complex preparatory training is given. For instance, those wishing to work in a boot camp are to complete a 4-week programme in the State of New York. The training material comprises management skills, consultancy techniques, psychology, resuscitation, military formulas, drills. [11] They have even unique training programmes from time to time for further training of those already working there. [10]

\section{Tragedies, Deaths}

Although as we mentioned, the physical and mental screening is necessary for most of the boot camp programmes before the youngsters are placed there but reports on deaths and injuries indicate that sometimes youngsters are sent there who either physically or mentally are inapt for the programme. [9] Below we shall present some detailed cases that had a major echo in the media, where death was attributable to the military training and discipline, training personnel, physical load or health conditions.

The case of Mario Cano ${ }^{4}$ (age 16) can be classified in the latter category, i.e. health causes; he was one of the teenagers to be the first to die in a boot camp. Mario's death was caused by a blood clot reaching his lungs 4 days after his inclusion in the camp. Although he

$4 \quad$ Date of death: April the $27^{\text {th }} 1984$, location: Tucson-based VisionQuest. 
was complaining to the training personnel about being ill, they thought he was simulating, therefore he was forced to carry on the physically burdensome physical exercises, during which he collapsed and died. During these short 4 days, camp nurses checked his health condition and no medic had him checked up. [12] Also, Nicholaus Contreraz ${ }^{5}$ (age 16) had health issues who died of a massive undiagnosed infestation, after he had lost his conscientiousness during training. Two weeks before his death, Nicholaus told a camp nurse about having breathing difficulties and that he was feeling pain in the chest and experiencing general weakness. He became incontinent and vomited several times a day. Instead of giving him appropriate care, the training personnel accused him of imitating this and started harassing him, thus, he was to undergo plenty of humiliation in the days before his death. [9]

In the history of boot camps, burdensome physical load resulted in several casualties. Among them Gina Scoret ${ }^{6}$ (age 14) who collapsed during a 2.6-mile jogging and died, suffering from heat exhaustion. She was overweight and not used to intensive physical exercise but the training personnel forced her to jog uninterruptedly. From time to time, they roped her to themselves to force her make constant motion until she dropped onto the ground. The personnel was waiting 3 hours after her collapse to call the ambulance as they thought her to be simulating feeling sick. [9] Similarly to Gina, Paul Choy (age 16) was unable to complete the 5-mile jogging set for him. As a punishment, the boy had to sit on a wooden platform for 5 hours in the cold. He was not allowed to shiver nor use the washroom for this period of time. Finally, when Paul gave up the exercise, the training personnel jumped on him right away and held him tight to the ground applying a so-called Nelson hold to him. They were holding him on the ground for 10 minutes and no sooner realised that the boy was no longer breathing being technically brain dead. [13] Therefore, in Paul's case also, the brutal excess of the training personnel attributed to the tragedy in addition to the basic physical ineptness. The conditions of the death of Martin Lee Anderson ${ }^{8}$ (age 14) have similar characteristics to that of Paul's, feeling sick after a 6-mile jogging and complaining of tiredness. Nonetheless, the training personnel obliged him to complete the jogging as he was also believed to simulate feeling sick. When Martin refused to continue the exercise, several members of the training personnel grabbed him in a way that they blocked his breathing. By the time they realised that the trouble is serious, it was too late, the boy had died. [14] The case was also recorded on a video footage, which was disclosed later on. Unfortunately, there are more who died by the hands of training officers due to being held down or detained: Anthony Green ${ }^{9}$ (age 15), Brandon Hadden ${ }^{10}$ (age 18).

Besides the health and physical issues raised so far, psychic inaptitude may also lead to tragedies. Suicide-although the examination of specific root causes and background is difficult-may be a sign of psychic inaptitude, which is an isolated case in boot camps either. Anthony Dumas ${ }^{11}$ (age 15) took his own life hanging himself with a belt on his double-deck bed. Chad Andrew Franza ${ }^{12}$ (age 16) also hung himself attaching the rope to

\footnotetext{
Date of death: March the $2^{\text {nd }} 1998$, location: Arizona Boys Ranch.

Date of death: July the $21^{\text {st }} 1999$, location: South Dakota State Training School.

Date of death: February the $4^{\text {th }} 1992$, location: Rite of Passage.

Date of death: January the $6^{\text {th }}$ 2006, location: Bay County Sheriff's Boot Camp.

Date of death: May the $21^{\text {st }} 1991$, location: Brookhaven Youth Ranch.

Date of death: October the $15^{\text {th }} 1998$, location: Healthcare Rehabilitation Center.

Date of death: October the $14^{\text {th }}$ 2000, location: Lippman Family Center in Broward County.

Date of death: August the $17^{\text {th }} 1998$, location: Polk County Boot Camp.
} 
the air vent of the air conditioning unit located in his room. Shawn Smith ${ }^{13}$ (age 13) was complaining of those abusing him who should be normally helping him then killed himself using the bed sheet attached to his door.

\section{Summary}

The strong military drill employed in boot camps entails negative impacts from several points of view. On the one hand, the relation with the aggressive and hostile training staff does not promote rehabilitation nor brings about long-term positive psychological and behavioural changes. On the other hand, enforcing participants to carry out heavy physical exercises may endanger their physical integrity and may even lead to death. [34] To avoid such strategies, more emphasis should be put in any event on physical and psychological assessment tests before including someone in this camp. At the same time, providing the proper specialist medical supervision would be necessary including the preparation of the training staff to be capable of recognising whether a young person is struggling with a serious issue or is just simulating. On the other hand, it is worth noting the maintenance of the proper mental health conditions of the personnel by means of providing regular further trainings or supervisions.

Ultimately, in any event, larger space should be given to various rehabilitation programmes, education, vocational training, employment and aftercare in addition to the military nature in boot camps established for youngsters. Efficiency tests demonstrate that military nature alone cannot achieve positive changes for the participants only if applied together with these programmes.

\section{References}

[1] GÜLTEKIN, K., GÜLTEKIN, S.: Is juvenile boot camp policy effective? International Journal of Human Science, 91 (2012), 725-740. https://doi.org/10.14687/ijhs.v9i1.1978

[2] RUZSONYI P.: Régi és új forma - Érvek és ellenérvek a csizmatáborokról. Börtönügyi Szemle, 3 (2000), 1-14.

[3] WILSON, D. B., MacKENZIE, D. L., MITCHELL, F. N.: Effects of Correctional Boot Camps on Offending. Campbell Systematic Reviews, 6 (2005), 1-42.

[4] SIMON, J.: They died with their boots on: the boot camp and the limits of modern penalty. Social Justice, 222 (1995), 25-48.

[5] MACKENZIE, D. L.: Boot camp prisons: components, evaluations, and empirical issues. Federal Probation, 543 (1990), 44-52.

[6] HUSZÁR L.: Csizmatábor létesítésének alternatívái Magyarországon. Börtönügyi Szemle, 3 (1999), 63-69.

[7] TYLER, J., DARVILLE, R., STALNAKER, K.: Juveline boot camps: a descriptive analysis of program diversity and effectiveness. The Social Science Journal, 38 (2001), 445-460.

13 Date of death: October the $30^{\text {th }}$ 2001, location: Volusia Regional Juvenile Detention Center Florida. 
[8] LUTZE, F. E.: Are shock incarceration programs more rehabilitative than traditional prisons? A survey of inmates. Justice Quarterly, 153 (1998), 547-566.

[9] MUSCAR, J. E.: Advocating the end of juvenile boot camps: Why the military model does not belong in the juvenile justice system. UC Davis Journal of Juvenile Law \& Policy, 121 (2008), 2-50.

[10] MACKENZIE, D. L, ARMSTRONG, G. S.: Correctional Boot Camps: Military Basic Training or a Model for Corrections? Thousand Oaks: SAGE Publications, 2004.

[11] MACKENZIE, D. L., HEBERT, E. E.: Correctional Boot Camps: A Tough Intermediate Sanction. Washington D.C.: National Institute of Justice, 1996.

[12] VisionQuest: The Best Alternative for Some. Los Angeles Times (online), June 16, 1985. http://articles.latimes.com/1985-06-16/local/me-2770_1_young-people (Downloaded: 10.12.2016)

[13] RIAK, J.: Deadly Restraint. 2006. http://nospank.net/camps.htm (Downloaded: 04.11.2016)

[14] REUTTER, D. M.: Youth Dies in Florida Boot Camp; Cause of Death Questioned. Prison Legal News (online), July 15, 2006. www.prisonlegalnews.org/news/2006/jul/15/youthdies-in-florida-boot-camp-cause-of-death-questioned/ (Downloaded: 11.12.2016) 